\title{
2-DE analysis of breast cancer cell lines 1833 and 4175 with distinct metastatic organ-specific potentials: Comparison with parental cell line MDA-MB-231
}

\author{
IRENA SELICHAROVA ${ }^{1}$, MILOSLAV SANDA ${ }^{1}$, JANA MLADKOVA ${ }^{1}$, SUJATA SARASWAT OHRI ${ }^{2}$, \\ ARUNA VASHISHTA ${ }^{2}$, MARTIN FUSEK ${ }^{1}$, JIRI JIRACEK ${ }^{1}$ and VACLAV VETVICKA ${ }^{2}$ \\ ${ }^{1}$ Institute of Organic Chemistry and Biochemistry, Academy of Sciences of the Czech Republic, Flemingovo nám. 2, \\ 16610 Prague, Czech Republic; ${ }^{2}$ Department of Pathology, University of Louisville, Louisville, KY 40202, USA
}

Received November 19, 2007; Accepted January 21, 2008

\begin{abstract}
Human MDA-MB-231 derived breast cancer cell lines 1833 and 4175 have different metastatic potentials in terms of their tissue tropisms and aggressiveness. Cell line 1833 is specifically metastatic to the bone. The highly aggressive cell line 4175 is specific to the lung. We performed 2-DE analysis of the cell lines. We found 16 significantly changed protein spots, 14 protein spots were identified. Expression of cathepsin D, triosephosphate isomerase, phosphoglycerate kinase 1 , heme binding protein 1 and annexin 2 could be correlated with the in vitro aggressiveness of the respective cell lines. Interstitial collagenase and dimethylargininase 2 were exclusive to the cell line 1833 and might contribute to its bone specificity. Serpin B9, cathepsin B chain b, galectin 3 and HSP 27 were changed in the lung specific cell line 4175 . The possible contribution of identified proteins to differences in metastatic behavior of the cell lines is discussed.
\end{abstract}

\section{Introduction}

Cancer metastases are responsible for the majority of cancerrelated deaths. Different types of cancer display various metastatic tissue tropisms. Breast cancer is a heterogeneous disease with diverse metastatic behavior. The frequent sites of breast cancer metastasis are bone and lung. Metastases to these sites differ in terms of their evolution, treatment, morbidity and mortality (1). Subpopulations of cells with enhanced metastatic abilities to either bone or to lung have been isolated by the group of J. Massague by in vivo selection of MDA-MB-231 cells $(2,3)$.

Correspondence to: Dr Irena Selicharova, Institute of Organic Chemistry and Biochemistry, Academy of Sciences of the Czech Republic, Flemingovo nám. 2, 16610 Prague, Czech Republic E-mail: selicharova@uochb.cas.cz

Key words: breast cancer, cell line, 2-DE, organ-specific metastases
The breast cancer cell line MDA-MB-231 was isolated in 1974 from a pleural effusion of a patient with disseminated disease relapsing several years after removal of her primary tumor (4). It is used as a model of estrogen receptor-negative and HER-2/neu-negative breast cancers. The cell line is highly aggressive both in vitro and in vivo (5). The in vivo selected subpopulations of MDA-MB-231 cells were obtained through serial reinoculation of culture expanded isolates from bone and lung lessions of xenografted MDA-MB-231 tumors to immunodeficient mice. Highly metastatic subpopulations with distinct organ-specific potentials were obtained. The cell line 1833 generated large osteolytic bone lesions invading the bone matrix. When grown subcutaneously or proliferated in culture it was not more aggressive than the parental cell line MDA-MB-231 (3). The cell line 4175 produced aggressive lung metastases and was markedly more tumorigenic then the parental cell line. Its ability to form bone metastases was inferior to that of the cell line 1833 (2). The group of J. Massague compared transcriptomic profiles of these cell line subpopulations and identified gene sets whose expression patterns are associated with formation of metastases either to bone or to lung $(2,3)$.

Recently, we have investigated the expression levels of procathepsin $\mathrm{D}(\mathrm{pCD})$, a zymogen of the lysosomal aspartic protease cathepsin $\mathrm{D}(\mathrm{CD})$, in MDA-MB-231 and its derived cell lines 1833 and 4175 . We have shown differential secretion of pCD in the MDA-MB-231 derived cell lines. The level of pCD secretion was the highest in the 4175 cell line and the lowest in the parental cell line MDA-MB-231. It correlated with the aggressiveness of the studied cell lines which has been assessed by an in vitro invasion assay (6).

The increased amount of data has documented an important role of $\mathrm{pCD}$ respective $\mathrm{CD}$ in cancer development. Overexpression of CD is correlated with metastatic potential of tumors (7). Although clinical studies using immunoassays have reported that $\mathrm{CD}$ is an independent marker of poor prognosis for breast cancer (8), the gene coding for CD is not included in the lists of poor prognosis genes such as a validated Rosetta-type poor prognosis signature (9) and others $(10,11)$.

Poor correlation of mRNA and protein levels is a known phenomenon (12). Proteins are ultimately responsible for most 
processes that take place within a cell. Proteomics is a rapidly developing approach towards a broad-based analysis of complex mixtures of proteins at a cellular or tissue levels (13). We analyzed the MDA-MB-231 derived cell lines with distinct metastatic potentials by the classical proteomical methodology combining 2-DE analysis with MS identification of selected proteins in order to explore differences among respective cell lines on the protein level.

\section{Materials and methods}

Cell culture and sample preparation. Human breast cancer cell line MDA-MB-231 was obtained from ATCC (Rockville, MD, USA). The derivative cells lines, 1833 and 4175 (LM2) were a kind gift from J. Massague (NY). Cells were maintained in RPMI-1640 medium (Sigma, St. Louis, MO, USA) with $10 \%$ heat-inactivated FCS (Hyclone, Logan, UT), 100 U/ml penicillin and $100 \mu \mathrm{g} / \mathrm{ml}$ streptomycin in plastic disposable tissue culture flasks at $37^{\circ} \mathrm{C}$ in a $5 \% \mathrm{CO}_{2} / 95 \%$ air incubator.

The cells grown to confluence were washed twice with PBS and then harvested by treating with trypsin, EDTA in PBS. The cells were pelleted by centrifugation at $800 \mathrm{~g}$ for $10 \mathrm{~min}$. The cell pellets were washed 3 times with PBS. After aspiration of the fluid the cells were lysed for $1 \mathrm{~h}$ in lysis buffer composed of $7 \mathrm{M}$ urea, $2 \mathrm{M}$ thiourea, $4 \%$ (w/v) CHAPS, $40 \mathrm{mM}$ Tris, $65 \mathrm{mM}$ DTT, $2 \%$ (v/v) ampholytes ( $\mathrm{pH} 9-11)$ using $60 \mu \mathrm{l}$ per $10^{6}$ cells. The lysate was centrifuged at $16,000 \mathrm{~g}$ for $10 \mathrm{~min}$. The protein content was determined using the Bradford assay (14). Aliquots of the cell lysates were stored at $-70^{\circ} \mathrm{C}$.

Two-dimensional gel electrophoresis. The cell lysate (70 $\mu \mathrm{g}$ of proteins for analytical gels, $400 \mu \mathrm{g}$ of proteins for preparative gels) was applied to $18 \mathrm{~cm}$ linear IPG strips $\mathrm{pH} 4-7$ or pH 6-9, GE Healthcare (Uppsala, Sweden). Composition of the buffer used for rehydratation of the $\mathrm{pH}$ 4-7 IPG strips was $7 \mathrm{M}$ urea, $2 \mathrm{M}$ thiourea, 4\% CHAPS, $50 \mathrm{mM}$ DTT, $0.8 \%$ ampholytes $\mathrm{pH}$ 3-10. Composition of the buffer used for rehydratation of the $\mathrm{pH}$ 6-9 IPG strips was $7 \mathrm{M}$ urea, $2 \mathrm{M}$ thiourea, 4\% CHAPS, 0.5\% ampholytes pH 6-9 and $12 \mu 1 / \mathrm{ml}$ DeStreak Reagent, GE Healthcare. 2-DE was performed exactly as described before only, the $12 \%$ (4\% stacking gel, $19 \times 22 \mathrm{~cm}$ ) polyacrylamide gels were used instead of the gradient gels (15).

The analytical gels were stained with silver stain according to the Bloom method modified by Rabilloud (16). The preparative gels were stained with the colloidal Coomassie stain (17).

Image analysis. Gels were scanned by GS-800 Calibrated Densitometer, Bio-Rad (Hercules, CA) at resolution of $700 \mathrm{dpi}$. The images were analyzed by PDQuest 2D Gel Analysis Software, Bio-Rad or submitted to Ludesi 2D Analysis Center (Lund, Sweden, http://www .ludesi.com).

The automatically generated spot detection and matching were checked manually. Within the gels analyzed by Ludesi, the differentially expressed proteins of interest were searched based on the fold-change between the average expression in groups of three replicate gels and on the probability values generated by ANOVA. The spots that changed 2-fold between any pair of the cell lines on probability level $p \leq 0.01$ were considered for further analysis.
PDQuest analysis was performed for each pair of the cell lines using the same set of parameters and the results were combined. The automatically detected spots were edited manually. Total density in gel image was chosen as a normalization method. The differentially expressed proteins were searched based on 2-fold change between average expressions in groups of four representative replicate gels at the probability level $\mathrm{p} \leq 0.05$ counted by the Student's t-test.

Mass spectrometric analysis and protein identification. Selected spots on the preparative gels were excised and destained using $50 \% \mathrm{ACN}$ in $25 \mathrm{mM}$ ammonium bicarbonate $\mathrm{pH} 7.8$, dehydrated with $200 \mu \mathrm{l}$ of $\mathrm{ACN}$ for $5 \mathrm{~min}$ at $30^{\circ} \mathrm{C}$ using thermo shaker, Eppendorf AG (Hamburg, Germany) at $30^{\circ} \mathrm{C}$ and then vacuum dried in Speed-vac, Labconco (Kansas, $\mathrm{MO})$. Gel pieces were rehydrated and proteins were digested for $8 \mathrm{~h}$ at $37^{\circ} \mathrm{C}$ in thermo shaker with $30 \mathrm{ng} / \mu 1$ trypsin (Trypsin Gold Mass Spectrometry Grade, Promega, Madison, WI) in $25 \mathrm{mM}$ ammonium bicarbonate $\mathrm{pH}$ 7.8. After digestion, peptides were extracted from gel pieces using step by step extraction with gradient of ACN (15-60\% ACN with $1 \%$ TFA). The extraction was performed in sonicator, Elma (Singen, Germany) with ice-cubes.

Extracted peptides were desalted and concentrated with Zip-Tip C18 tips, Millipore (Billerika, MA). MALDI-TOF MS and tandem ESI-MS were used to characterize the digests. The MALDI-TOF analysis and protein identification based on peptide mass fingerprinting was performed exactly as described previously (15). The tandem ESI-MS was performed on Q-TOF Micro mass spectrometer (Waters-Micromass) equipped with nanoelectrospray source and coupled to 2D capillary chromatography CapLC (Waters). Chromatographic separation was achieved using symmetry $300 \AA$ ( $1 \mathrm{~cm}$ x $5 \mu \mathrm{m})$ trap column and Atlantis dC18 $(75 \mu \mathrm{m} \times 10 \mathrm{~cm} \times 3 \mu \mathrm{m})$ capillary column. Data were processed by proteomic software Proteinlynx global server 2.1 (Waters) (LC-MS/MS).

Immunobloting. Extracts $(50 \mu \mathrm{g})$ from 4175 cells were separated by 2-DE (7 cm IPG strips pH 3-10 Bio-Rad, 11\% SDS polyacrylamide gels) and electroblotted onto Immobilon $\mathrm{P}$ membrane at $3 \mathrm{~mA} / \mathrm{m}^{2}$ for $1 \mathrm{~h}$ in $20 \mathrm{mM} \mathrm{CAPS} / \mathrm{NaOH}$ buffer $\mathrm{pH} 10.3$ containing $10 \%(\mathrm{v} / \mathrm{v})$ methanol and $0.1 \%(\mathrm{w} / \mathrm{v})$ SDS. All incubations and washes were performed at room temperature with $50 \mathrm{mM}$ Tris/ $\mathrm{HCl}$ buffer $\mathrm{pH} 7.5$ containing $140 \mathrm{mM}$ $\mathrm{NaCl}$ and $0.1 \%(\mathrm{v} / \mathrm{v})$ Tween-20 (T-TBS). Membranes were blocked with $3 \%(\mathrm{w} / \mathrm{v})$ bovine serum albumin in T-TBS overnight. Membranes were then incubated for $1 \mathrm{~h}$ with mouse monoclonal anti-CD antibody Sigma (1/1,000 in T-TBS with $3 \%$ bovine serum albumin), washed with T-TBS and incubated for $1 \mathrm{~h}$ with anti-mouse peroxidase conjugated antibody, Sigma $(1 / 12,000$ in T-TBS with $3 \%$ bovine serum albumin). The membranes were then washed with T-TBS and developed with diaminobenzidine.

\section{Results}

2-DE. The 2-DE gels were prepared from three different cell batches of the MDA-MB-231, 1833 and 4175 cell lines. The gels in $\mathrm{pH}$ range 4-7 and $\mathrm{pH}$ range 6-9 were prepared. Two technical replicates of analytical gels were prepared from each sample, in total 6 gels per each cell line in the respective 


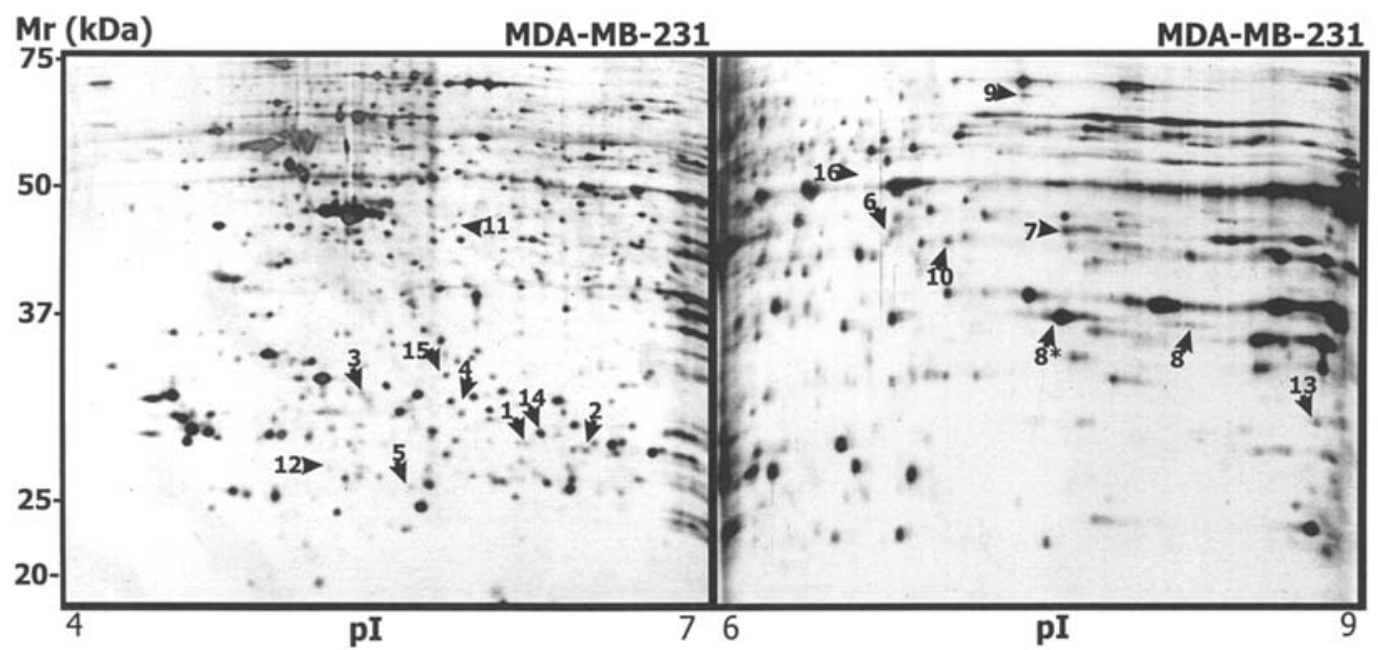

Figure 1. Representative 2-DE maps of proteins of MDA-MB-231 breast cancer cell line. The gels were silver stained. Solubilized proteins were focused on IPG strips pH 4-7 and pH 6-9 and separated in 12\% SDS polyacrylamide gels. For experimental details see Materials and methods. The proteins identified in numbered spots are listed in Table I.

Table I. Differentially expressed proteins in MDA-MB-231 cell line and cell lines 1833 and 4175.

\begin{tabular}{|c|c|c|c|c|c|c|c|c|c|}
\hline \multirow{2}{*}{$\begin{array}{l}\text { Spot } \\
\text { no. }\end{array}$} & \multirow{2}{*}{$\begin{array}{c}\text { Accession } \\
\text { no. }\end{array}$} & \multirow{2}{*}{$\begin{array}{c}\text { Protein } \\
\text { name }\end{array}$} & \multicolumn{3}{|c|}{ Fold change } & \multirow{2}{*}{$\begin{array}{l}\mathrm{Mr} / \mathrm{pI} \\
\text { theor. }\end{array}$} & \multirow{2}{*}{$\begin{array}{l}\mathrm{Mr} / \mathrm{pI} \\
\text { meas. }\end{array}$} & \multirow{2}{*}{$\begin{array}{c}\text { Seq. } \\
\text { cov. }(\%)\end{array}$} & \multirow{2}{*}{$\begin{array}{l}\text { Pept. } \\
\text { assign }\end{array}$} \\
\hline & & & $1833 / 231$ & $4175 / 231$ & $4175 / 1833$ & & & & \\
\hline 1 & P60174 & Triosephosphate isomerase & 2 & 4.8 & 2.3 & $26 / 6.5$ & $26 / 6.1$ & 61 & 11 \\
\hline 2 & P60174 & Triosephosphate isomerase & 2 & 3 & 1.6 & $26 / 6.5$ & $26 / 6.4$ & 58 & 9 \\
\hline 3 & P07339 & Cathepsin D chain b & 2.5 & 4.2 & 1.7 & $27 / 5.6$ & $28 / 5.4$ & 24 & 5 \\
\hline 4 & P07339 & Cathepsin D chain b & $\mathrm{nd}^{\mathrm{a}}$ & $\mathrm{nd}^{\mathrm{a}}$ & 4 & $27 / 5.6$ & $28 / 5.8$ & 26 & 5 \\
\hline 5 & Q9NRV9 & Heme binding protein 1 & 2.4 & 3.5 & 1.4 & $21 / 5.7$ & $23 / 5.6$ & 33 & 5 \\
\hline 6 & P00558 & Phosphoglycerate kinase 1 & 2.3 & 4.9 & 2.2 & $44 / 8.3$ & $45 / 6.7$ & 15 & $5^{b}$ \\
\hline 7 & P00558 & Phosphoglycerate kinase 1 & 4.1 & 4.6 & 1.1 & $44 / 8.3$ & $45 / 7.5$ & 15 & $5^{b}$ \\
\hline $8^{* c}$ & P07355 & Annexin 2 & 1.1 & 1.5 & 1.3 & $38 / 7.5$ & $37 / 7.5$ & 36 & 11 \\
\hline 8 & P07355 & Annexin 2 & 2.8 & 13 & 4.6 & $38 / 7.5$ & $37 / 8$ & 31 & 9 \\
\hline 9 & & Unidentified & 0.3 & 0.4 & 1.3 & & $43 / 7$ & & \\
\hline 10 & & Unidentified & 0.13 & 0.1 & 0.7 & & $70 / 7.4$ & & \\
\hline 11 & P50453 & Serpin B9 & 1.4 & 5 & 3.6 & $42 / 5.6$ & $40 / 5.7$ & 32 & 9 \\
\hline 12 & P07858 & Cathepsin B chain b & 0.6 & 5.4 & 9 & $23 / 5.2$ & $23 / 5.2$ & 39 & 6 \\
\hline 13 & P17931 & Galectin 3 & 0.7 & 2.6 & 4 & $26 / 8.6$ & $29 / 8.7$ & 19 & 4 \\
\hline 14 & P04792 & Heat shock protein 27 & 1.5 & 0.2 & 0.14 & $23 / 6$ & $26 / 6.2$ & 32 & 5 \\
\hline 15 & O95865 & Dimethylargininase 2 & 2.6 & 1.2 & 0.46 & $29 / 5.7$ & $29 / 5.7$ & 22 & 4 \\
\hline 16 & P03956 & Interstitial collagenase & 9.8 & 0.7 & 0.07 & $54 / 6.5$ & $52 / 6.6$ & 14 & $6^{b}$ \\
\hline
\end{tabular}

Differentially expressed proteins identified from the 2-DE gels of MDA-MB-231 breast cancer cell line and its derived cell lines 1833 and 4175. For each protein spot we show the accession no. to the Swiss-Prot database of the identified protein, the protein name, the fold change of expression in the derived cell lines in proportion to the expression in the MDA-MB-231 cell line (4175/231 and 1833/231) and mutually (4175/1833), theoretical (theor.) and experimentally found (meas.) relative molecular weight in $\mathrm{kDa}$ and isoelectric point (Mr/pI), sequence

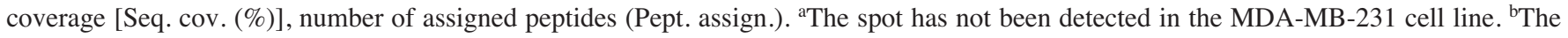
spot has been identified both with LC-MS/MS and mass fingerprinting. 'Quantification of the spot is approximate due to its saturation in silver stained gels. Details are given in Results.

$\mathrm{pH}$ range. Representative gels of the parental cell line MDAMB-231 are shown in Fig. 1.
Image analysis in the $\mathrm{pH}$ range 4-7. The scanned images were processed using the PDQuest 2D Gel Analysis Software. One representative gel from each cell batch was submitted to 

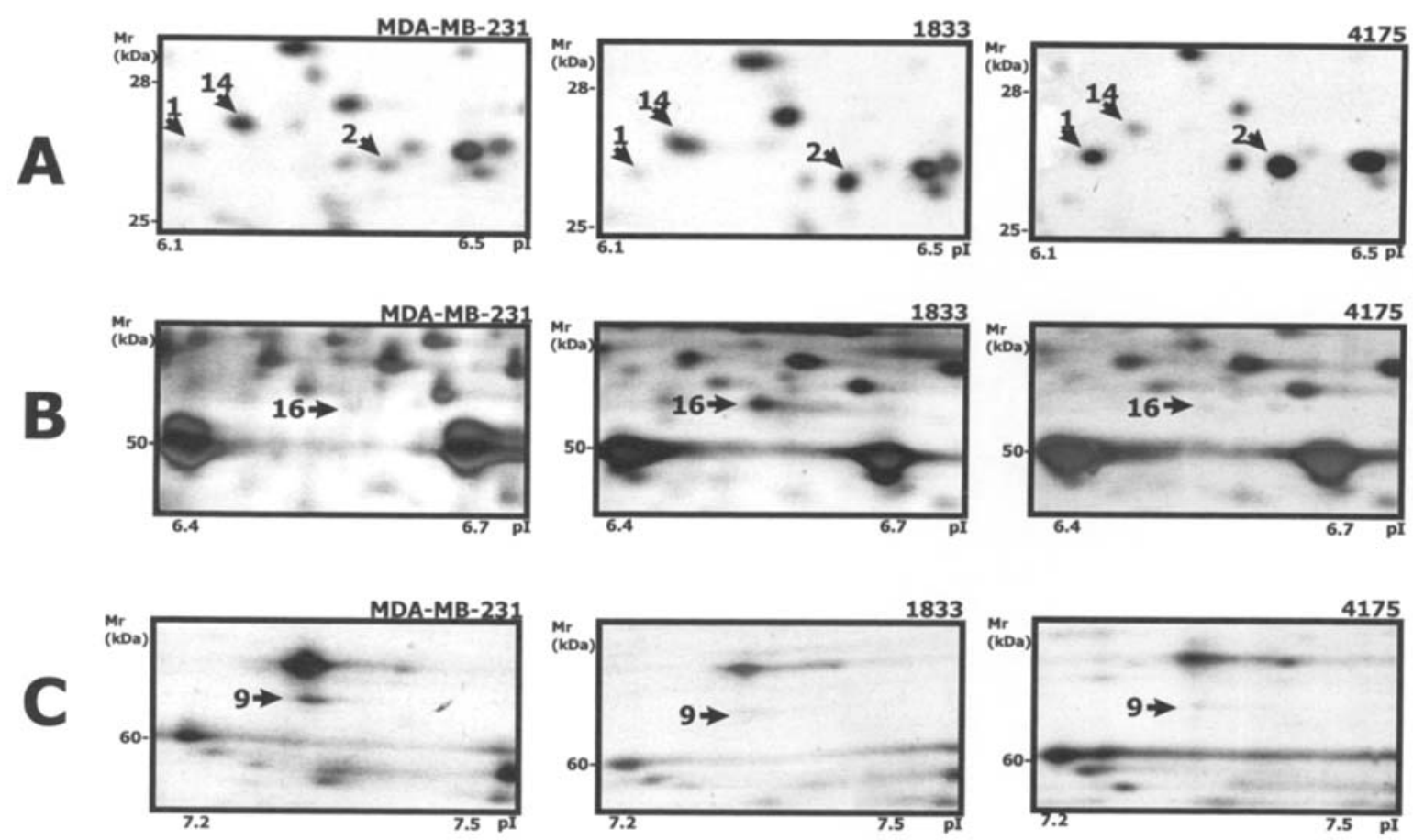

Figure 2. Enlarged sections of the 2-DE gels of proteins from MDA-MB-231 cell line and its derived cell lines 1833 and 4175 . Examples of the trends in differential expression of proteins (spots). (A) Expression of spots 1 and 2 correlated with growing aggressiveness of the cell lines. Spot 14 was solely decreased in the cell line 4175. (B) Spot 16 was solely increased in the cell line 1833. (C) Spot 9 was solely increased in the parental MDA-MB-231 cell line. The spots are marked by the same numbers as in Table I.

the Ludesi 2D analysis center (http://www.ludesi.com) i.e. three gels per each cell line. We detected in average $1123 \pm 85$ spots, 516 spots matched between all the gels. The matched spots with relative average volume above 500 units present in all the replicated gels and with at least 2-fold difference at the ANOVA counted probability level $\mathrm{p} \leq 0.01$ were considered as differentially expressed proteins in the $\mathrm{pH}$ range $4-7$. The automatically generated spots found using the above criteria were subjected to a visual survey. The spots that were located in marginal areas of the gels or that were parts of strikes or large spot clusters were excluded from comparisons. They were not reliable and could not be cut from the preparative gels properly. We found nine differentially expressed proteins fulfilling our criteria. Description of the spots is given in Table I and they are marked in Fig. 1.

Image analysis in the $p H$ range 6-9. The images in the area of alkaline $\mathrm{pH}$ showed fewer spots. Quality of the images was not as good as of the images in the area of $\mathrm{pH} 4-7$. The image analysis using the PDQuest 2D Gel Analysis Software was performed. We detected in average $749 \pm 97$ spots, 197 spots matched among all the gels. Two-fold change at probability level $\mathrm{p} \leq 0.05$ counted using the Student's t-test between each pair of the cell lines was considered as significant. We inspected the gels visually and confronted our observations with the PDQuest analysis. We found seven spots fulfilling our criteria. Description of the spots is given in Table I and they are marked in Fig. 1.

Differentially expressed proteins. Sixteen protein spots were found as significantly changed. Eight (spots 1-8) of them showed a gradual increase being the lowest in the parental cell line MDA-MB-231, about 2-fold increased in the bone specific 1833 cell line and the most increased in the most aggressive lung specific 4175 cell line. Expression of these proteins could be correlated with the growing aggressiveness assessed by the in vitro invasion assay of the respective cell lines (6). An example of spots 1 and 2 that follow the above mentioned trend of expression is shown in Fig. 2A. The other eight spots [9-16] were selectively increased or decreased only in one of the cell lines. Two of them were changed in the parental MDA-MB-231 cell line (spots 9 and 10), four were changed in the lung specific 4175 cell line (spots 11-14) and two (spots 15 and 16) were changed in the bone specific 1833 cell line. Examples of proteins changed selectively in the respective cell lines are shown in Fig. 2. Spot 14 was solely decreased in the cell line 4175 (Fig. 2A), spot 16 was solely increased in the cell line 1833 (Fig. 2B) and spot 9 was solely increased in the parental MDA-MB-231 cell line (Fig. 2C).

Protein identification. For identification of proteins from 2-DE gels we used a combination of tryptic digestion, MALDI-TOF spectrometry and of the search in protein databases. Protein identification was considered reliable when it was significant $(\mathrm{p}<0.05)$ according to the search probability based MOWSE score. The proteins were identified in at least two independent experiments. The LC-MS/MS was used to confirm identification in the cases when we could not achieve highly significant identification using peptide mass fingerprinting.

We have identified 14 spots out of the 16 differentially expressed protein spots (Table I). The unidentified proteins were located in the area of alkaline $\mathrm{pH}$. The protein resolution 


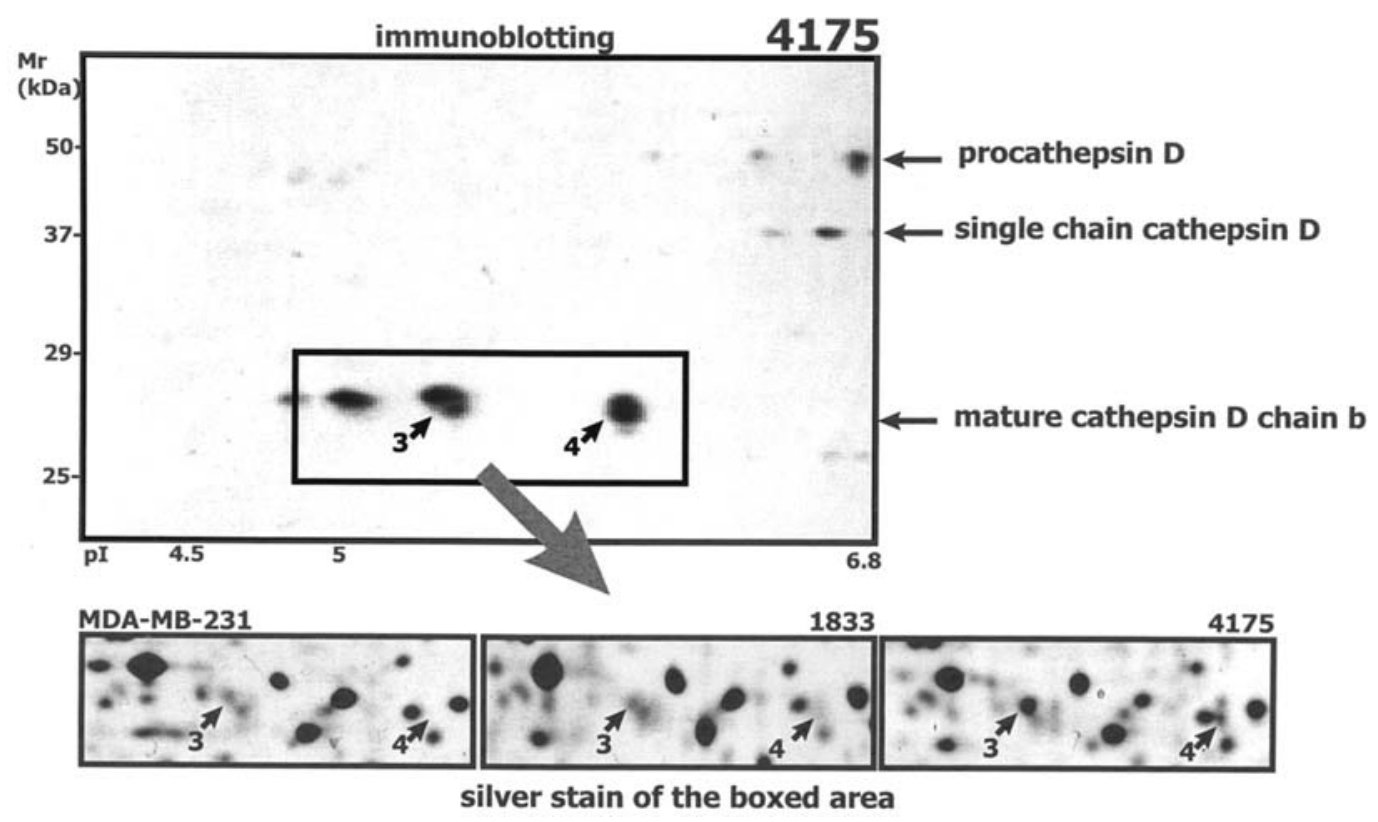

Figure 3. Immunoblot analysis of proteins from the cell line 4175. Proteins were separated by 2-DE and detected with mouse monoclonal anti-cathepsin D antibody. The sections of silver stained gels from the MDA-MB-231 cell line and the cell lines 1833 and 4175 with differentially expressed spots of cathepsin D are shown.

in this $\mathrm{pH}$ range was not very good and was worsened with the increased loads of proteins in preparative gels.

Spots 1 and 2 were identified as triosephosphate isomerase (TPI). TPI is known to be phosphorylated on serine 21 (Swiss-Prot database, http://www.expasy.org, accession no. P60174). We presume that the more acidic spot is phosphorylated.

Spots 3 and 4 have been identified as cathepsin D (CD chain b). Recently, we have shown the differential secretion of pCD by the MDA-MB-231 derived cell lines (6). Here we confirmed the differential expression of $\mathrm{CD}$ also on the proteome level. We performed immunodetection of $\mathrm{CD}$ in the 2D gels (Fig. 3). We detected multiple forms of CD. Two spots corresponding to the chain $\mathrm{b}$ of mature $\mathrm{CD}$ (spots 3 and 4) were changed with statistical significance and were identified by MALDI-TOF analysis (Table I). The smeary pattern of the spots can be attributed to their glycoside moieties. The presence of isoelectric variants of CD might signify the presence of charged groups in the glycoside moieties.

Spot no. 5 was identified as heme binding protein 1. Spots no. 6 and 7 were identified as phosphoglycerate kinase 1 (PGK1). There are three phosphorylation sites in the amino acid sequence of PGK1 (Swiss-Prot data-base, http://www. expasy.org, accession no. P00558). We assume that the spots detected correspond to the differentially phosphorylated species of PGK1. The peptide mass fingerprinting have not yielded satisfactory results. The protein in both spots was identified through LC-MS/MS technology.

Spot no. 8 was identified as annexin 2. However, the theoretical $\mathrm{pI}$ value of annexin 2 corresponds to an abundant spot located nearby (indexed as $8^{*}$ in Fig. 1 and in Table I). We confirmed it by MS analysis. The spot was saturated and we could not quantify it by PDQuest. There are five phosphorylation sites in the amino acid sequence of annexin 2
(Swiss-Prot database, http://www.expasy.org, accession no. P07355). We cannot distinguish whether the significantly changed spot 8 is a post-translationally modified form of annexin 2 or whether it is a streak from the main spot or whether it is another protein which is overlaid by the streak from annexin 2. Although we could not identify any other protein based on the mass spectra after exclusion the peaks assigned to the annexin 2, we cannot consider this identification reliable.

Two spots ( 9 and 10) were increased in the parental cell line compared to the derived cell lines. We have not succeeded in identification of these spots.

Four other spots were changed only in the lung specific cell line 4175. Three of them identified as serpin B9 (spot 11), cathepsin B chain b (spot 12) and galectin 3 (spot 13) were increased, the fourth protein identified as HSP 27 (spot 14) was decreased.

Galectin 3 was identified with relatively low sequence coverage. However the first trypsin cleavage site is Arg 129 thus it is impossible to obtain better results with our methodo$\operatorname{logy}$. The identification was successful in two independent experiments and we consider it reliable.

We have found two proteins exclusively enriched in the bone specific cell line 1833. Spot no. 15 has been identified as dimethylargininase 2 (DDAH) and spot no. 16 as interstitial collagenase (matrix metalloproteinase-1 or MMP1).

\section{Discussion}

The MDA-MB-231 derived cell lines 1833 and 4175 have different metastatic potentials in terms of their tissue tropisms and aggressiveness. The cells were isolated by the group of $\mathrm{J}$. Massague. Sets of genes that mark and mediate breast cancer metastasis respectively to bone and lung have been identified and clinically validated $(2,3)$. We performed the 2 -DE 
analysis of the MDA-MB-231-derived breast cancer cell lines and found 16 differentially expressed protein spots in the gels of $\mathrm{pH}$ ranging from 4 to 9 . The 2-DE profiles of the respective cell lines were very similar. We detected only a few spots that fulfilled our criteria in terms of fold-change and statistical significance, while Kang et al (3) and Minn et al (2), respectively found 102 genes that were significantly changed between the parental and bone specific cell lines and 95 genes changed in the lung specific cell line. Many genes in the identified sets encoded secretory or cell surface proteins. Such proteins are not expected to be resolved in the 2-DE gels (18). However, with the exception of MMP1 (spot 16), none of the proteins identified in our analysis were included in the gene lists. This finding is not surprising and it is in accordance with observations of others. For example, Spreafico et al (19) studied osteoblastic cell proliferation and differentiation by comparative 2-DE. They identified proteins important for definition of osteoblast differentiation stage but they failed to detect any significant change of the classical markers of gene expression of osteoblast differentiation.

We observed several trends in the protein expressions between the cell lines. Expression of eight protein spots could be correlated with the aggressiveness of the respective cell lines, the highest being in the 4175 cell line and the lowest in the parental cell line MDA-MB-231 as it was assessed from the in vitro invasion assay (6). Two of them, spots 3 and 4 were identified as CD chain b (Fig. 3), another two spots 1 and 2 following the same trend were identified as TPI (Fig. 2A) and finally two spots, 6 and 7, were identified as PGK1. Differential change of the two spots of the same protein (Table I) that are representing isoelectric variants suggests that not only overexpression of the respective proteins but also their post-translational regulation takes place in acquisition of the aggressive phenotype.

Overexpression of $\mathrm{CD} / \mathrm{pCD}$ in breast cancer is associated with increased risk of metastasis (7). Recently we have demonstrated a direct relationship between expression and secretion of pCD and differential invasive potentials of MDA-MB-231 derived cell lines (6). We could not detect pCD in the 2-DE analysis of the cell lysates. Although the spots corresponding to pCD were detectable in the immunoblot (Fig. 3) they were probably too slight to be distinguishable in the analytical 2-DE gels. This suggests that pCD is either immediately secreted from the cells where it exerts its suggested mitogenic function (20) or it is further processed to its mature form which serves its intracellular functions (21).

TPI and PGK1 are enzymes of glycolysis. Zhang et al (22) reported overexpression of TPI and PGK1 in HER-2/neu overexpressing cell lines and HER-2/neu-positive tumors. They suggested that PGK1 expression is regulated by HER-2/ neu status in breast cancer. We checked the possibility using flow cytometry approach that the expression of HER-2/neu is increased in the cell line 4175 (data not shown). We have not found any change in expression of this breast cancer prognostic marker. The increase of glycolysis enzymes in cancer cells is thought to be related to the increased requirements of energy in the rapidly growing tumors. It does not seem that it is a cause of carcinogenesis but it is rather its consequence. We assume that the same effect (i.e., TPI and/or PGK1 overexpression) can be induced by various causes. The expression of TPI has been shown to be regulated by cytokines interferon- $\gamma$ and tumor necrosis factor in ME-180 cervical carcinoma cells (23). We have shown that pCD stimulates secretion of various cytokines in breast cancer cell lines (6). Whether extracellular pCD might influence the TPI and/or pGK1 levels should be further explored.

Expression of two other spots, 5 and 8, correlated with growing aggressiveness of the studied cell lines. Spot no. 5 has been identified as heme binding protein 1 . The protein binds with a high affinity to heme or porphyrins (24). We have not found any extensive information on a possible role of this protein.

Spot no. 8 was identified as annexin 2. Function of this protein in cancer has been broadly discussed $(25,26)$. However, we cannot consider this identification reliable for reasons explained in the results.

The other eight protein spots were changed selectively in only one of the cell lines. Interpretation of the importance of these changes is not as evident as it is in the case of proteins with expression correlated with growing aggressiveness of the cell lines. The proteins might be important for the metastatic specificity of the respective cell lines but might signify other qualities of the cell lines, such as an invasive potential, angiogenetic potential and so on.

Two spots, 9 and 10, were elevated in the parental cell line compared to the derived cell lines. Unfortunately, we have not succeeded in identification of these spots. The importance of these proteins is difficult to forecast.

The bone-specific cell line 1833 showed very little difference when compared to the parental MDA-MB-231 cell line. We assume that the proteins exclusive to this cell line (MMP1, DDAH) contribute to its bone specificity. MMP1 (spot 16) was the only protein identified in our study that had also been found in the gene expression study performed by the group of J. Massague (3). MMP1 promotes osteolysis by cleaving a specific peptide bond in the collagen of bone matrix (27). Interestingly, the protein has also been found elevated in the gene expression study of the lung specific cell line 4175 (2). In our study, it was exclusively found in the bone-specific cell line 1833 (Fig. 2B). The other protein, DDAH (spot 15), has a role in nitric oxide generation. Production of nitric oxide is one of the factors involved in angiogenesis. Glioma C6 cells constitutively overexpressing DDAH when injected to nu/nu mice resulted in faster growing tumors with increased vascularization compared to the wildtype glioma C6 cells (28). The increased angiogenic potential might contribute to the ability of MDA-1833 cells to colonize the bone.

We have found additional changes in the lung specific cell line 4175 relative to the parental cell line MDA-MB-231. The possible functions of the identified proteins are varied. Serpin B9 (spot 11) is a specific inhibitor of serine protease granzyme B. Granzyme B is a main effector molecule of cytotoxic $\mathrm{T}$ lymphocytes and natural killer cells. It was suggested that serpin B9 expression by neoplastic cells may constitute one of the mechanisms for tumors to escape immune surveillance (29). Cathepsin B (spot 12) is a lysosomal cysteine protease involved in intracellular proteolysis. The secreted protease binds to the tumor cell surface predominantly at the invasive edge. It causes matrix degradation and promotes 
invasion of cancer cells (26). Galectin 3 (spot 13) is a secreted ß-galactoside-binding lectin mediating cell-cell and cellmatrix interactions (30). Although its level in the cell line 4175 was not increased dramatically (Table I), it might contribute to the metastatic specificity of the cell line 4175 to the lungs through mediating cell-cell interactions. HSP 27 (spot 14) was selectively decreased in the cell line 4175. Vast amounts of literature exists regarding the role of HSP 27 in cancer reporting its overexpression resulting in resistance to apoptotic processes (31). We have observed a decrease of the level of HSP 27 in the cell line 4175 which is in contrary to the reports on its role in cancer. Williams et al (32) observed up to 25-fold variance in abundance of HSP 27 in various breast cancer cell lines. The level of HSP 27 in normal breast epithelial cells was intermediate relative to the tumor cell lines. According to the data of Williams et al (32) the level of HSP 27 in MDA-MB-231 cell line was decreased respective to the normal cells. It is evident that the role of HSP 27 in cancer is more complicated and any deviation from normal might have fatal consequences.

Minn et al (2) in their transcriptomic analysis concluded that the genes of the lung metastasis signature are more tumorigenic and seem to enhance growth both within the breast and the lung. Although we have employed different approach and found different gene products then Minn et al (2), our conclusions are similar. The proteins found increased only in the cell line 4175 such as cathepsin B or serpin B9 are related rather to aggressiveness (26) and viability (29) of the cells than to the lung specificity but might also favor the homing in visceral tissues.

Most of the proteins identified in our study, including CD, HSP 27, TPI, PGK1 and MMP1, have been implicated in cancinogenesis before $(6,31,22,27)$. Thus far, the exact influence and regulation of these proteins in cancer cells and tissues is not completely understood. Our results further highlight their importance.

\section{Acknowledgements}

We would like to thank to Ms. Lucia Svitekova for technical assistance. This study was supported by a grant from the Ministry of Health of the Czech Republic (NR/8323-3, J.V., J.J. and E.M.), the Research Project of the Academy of Sciences of the Czech Republic (Z40550506, J.J.) and the NIH grant ROI CAA082159-03.

\section{References}

1. Solomayer EF, Diel IJ, Meyberg GC, Gollan C and Bastert G: Metastatic breast cancer: clinical course, prognosis and therapy related to the first site of metastasis. Breast Cancer Res Treat 59: 271-278, 2000.

2. Minn AJ, Gupta GP, Siegel PM, Bos PD, Shu WP, Giri DD, Viale A, Olshen AB, Gerald WL and Massague J: Genes that mediate breast cancer metastasis to lung. Nature 436: 518-524, 2005.

3. Kang YB, Siegel PM, Shu WP, Drobnjak M, Kakonen SM, Cordon-Cardo C, Guise TA and Massague J: A multigenic program mediating breast cancer metastasis to bone. Cancer Cell 3: 537-549, 2003.

4. Cailleau R, Young R, Olive M and Reeves WJ Jr: Breast tumor cell lines from pleural effusions. J Natl Cancer Inst 53: 661-674, 1974.
5. Rochefort H, Glondu M, Sahla ME, Platet N and Garcia M: How to target estrogen receptor-negative breast cancer? Endocr Relat Cancer 10: 261-266, 2003.

6. Ohri SS, Vashishta A, Vetvickova J, Fusek M and Vetvicka V: Procathepsin D expression correlates with invasive and metastatic phenotype of MDA-MB-231 derived cell lines. Int J Biol Macromol 41: 204-209, 2007.

7. Rochefort H, Capony F, Garcia M, Cavailles V, Freiss G, Chambon M, Morisset M and Vignon F: Estrogen-induced lysosomal proteases secreted by breast-cancer cells - a role in carcinogenesis. J Cell Biochem 35: 17-29, 1987.

8. Bossard N, Descotes F, Bremond AG, Bobin Y, De Saint Hilarie P, Golfier F, Awada A, Mathevet PM, Berrerd L, Barbier $\mathrm{Y}$ and Esteve J: Keeping data continuous when analyzing the prognostic impact of a tumor marker: an example with cathepsin D in breast cancer. Breast Cancer Res Treat 82: 47-59, 2003.

9. Van't Veer LJ, Dai HY, van de Vijver MJ, He YDD, Hart AAM, Mao M, Peterse HL, van der Kooy K, Marton MJ, Witteveen AT, Schreiber GJ, Kerkhoven RM, Roberts C, Linsley PS, Bernards R and Friend SH: Gene expression profiling predicts clinical outcome of breast cancer. Nature 415: 530-536, 2002.

10. Pawitan Y, Bjohle J, Amler L, Borg AL, Egyhazi S, Hall P, Han X, Holmberg L, Huang F, Klaar S, Liu ET, Miller L, Nordgren H, Ploner A, Sandelin K, Shaw PM, Smeds J, Skoog L, Wedren S and Bergh J: Gene expression profiling spares early breast cancer patients from adjuvant therapy: derived and validated in two population-based cohorts. Breast Cancer Res 7: R953-R964, 2005

11. Grigoriadis A, Mackay A, Reis-Filho JS, Steele D, Iseli C, Stevenson BJ, Jongeneel CV, Valgeirsson H, Fenwick K, Iravani M, Leao M, Simpson AJ, Strausberg RL, Jat PS, Ashworth A, Neville AM and O'Hare MJ: Establishment of the epithelial-specific transcriptome of normal and malignant human breast cells based on MPSS and array expression data. Breast Cancer Res 8: R56, 2006.

12. Lottspeich F: Proteome analysis: a pathway to the functional analysis of proteins. Angew Chem Int Edit 38: 2477-2492, 1999.

13. Patterson SD and Aebersold RH: Proteomics: the first decade and beyond. Nat Genet 33: 311-323, 2003.

14. Bradford MM: A rapid and sensitive method for the quantitation of microgram quantities of protein utilizing the principle of protein-dye binding. Anal Biochem 72: 248-254, 1976.

15. Selicharova I, Smutna K, Sanda M, Ubik K, Matouskova E, Bursikova E, Brozova M, Vydra J and Jiracek J: 2-DE analysis of a new human cell line EM-G3 derived from breast cancer progenitor cells and comparison with normal mammary epithelial cells. Proteomics 7: 1549-1559, 2007.

16. Rabilloud T: A comparison between low background silver diammine and silver-nitrate protein stains. Electrophoresis 13: 429-439, 1992.

17. Candiano G, Bruschi M, Musante L, Santucci L, Ghiggeri GM, Carnemolla B, Orecchia P, Zardi L and Righetti PG: Blue silver: a very sensitive colloidal Coomassie G-250 staining for proteome analysis. Electrophoresis 25: 1327-1333, 2004.

18. Zuo X, Echan L, Hembach P, Tang HY, Speicher KD, Santoli D and Speicher DW: Towards global analysis of mammalian proteomes using sample prefractionation prior to narrow $\mathrm{pH}$ range two-dimensional gels and using one-dimensional gels for insoluble and large proteins. Electrophoresis 22: 1603-1615, 2001.

19. Spreafico A, Frediani B, Capperucci C, Chellini F, Paffetti A, D'Ambrosio C, Bernardini G, Mini R, Collodel G, Scaloni A, Marcolongo R and Santucci A: A proteomic study on human osteoblastic cells proliferation and differentiation. Proteomics 6 : 3520-3532, 2006.

20. Vetvicka V, Benes P and Fusek M: Procathepsin D in breast cancer: what do we know? Effects of ribozymes and other inhibitors. Cancer Gene Ther 9: 854-863, 2002.

21. Garcia M, Platet N, Liaudet E, Laurent V, Derocq D, Brouillet JP and Rochefort H: Biological and clinical significance of cathepsin $\mathrm{D}$ in breast cancer metastasis. Stem Cells 14: 642-650, 1996.

22. Zhang DH, Tai LK, Wong LL, Chiu LL, Sethi SK and Koay ESC: Proteomic study reveals that proteins involved in metabolic and detoxification pathways are highly expressed in HER-2/neupositive breast cancer. Mol Cell Proteomics 4: 1686-1696, 2005.

23. Matsui NM, Smith DM, Clauser KR, Fichmann J, Andrews LE, Sullivan CM, Burlingame AL and Epstein LB: Immobilized pH gradient two-dimensional gel electrophoresis and mass spectrometric identification of cytokine-regulated proteins in ME-180 cervical carcinoma cells. Electrophoresis 18: 409-417, 1997. 
24. Blackmon BJ, Dailey TA, Xiao LC and Dailey HA: Characterization of a human and mouse tetrapyrrole-binding protein. Arch Biochem Biophys 407: 196-201, 2002.

25. Gerke V, Creutz CE and Moss SE: Annexins: linking Ca2+ signalling to membrane dynamics. Nat Rev Mol Cell Biol 6: 449-461, 2005.

26. Mai J, Waisman DM and Sloane BF: Cell surface complex of cathepsin B/annexin II tetramer in malignant progression. Biochim Biophys Acta 1477: 215-230, 2000.

27. Holliday LS, Welgus HG, Fliszar CJ, Veith GM, Jeffrey JJ and Gluck SL: Initiation of osteoclast bone resorption by interstitial collagenase. J Biol Chem 272: 22053-22058, 1997.

28. Kostourou V, Robinson SP, Whitley GSJ and Griffiths JR: Effects of overexpression of dimethylarginine dimethylaminohydrolase on tumor angiogenesis assessed by susceptibility magnetic resonance imaging. Cancer Res 63: 4960-4966, 2003.
29. Van Houdt IS, Oudejans JJ, van den Eertwegh AJM, Baars A, Vos W, Bladergroen BA, Rimoldi D, Muris JJFJ, Hooijberg E, Gundy CM, Meijer CLM and Kummer JA: Expression of the apoptosis inhibitor protease inhibitor 9 predicts clinical outcome in vaccinated patients with stage III and IV melanoma. Clin Cancer Res 11: 6400-6407, 2005.

30. Shekhar MP, Nangia-Makker P, Tait L, Miller F and Raz A: Alterations in galectin-3 expression and distribution correlate with breast cancer progression: functional analysis of galectin-3 in breast epithelial-endothelial interactions. Am J Pathol 165: 1931-1941, 2004.

31. Arrigo AP, Simon S, Gibert B, Kretz-Remy C, Nivon M, Czekalla A, Guillet D, Moulin M, az-Latoud C and Vicart P: Hsp27 (HspB1) and alphaB-crystallin (HspB5) as therapeutic targets. FEBS Lett 581: 3665-3674, 2007.

32. Williams K, Chubb C, Huberman E and Giometti CS: Analysis of differential protein expression in normal and neoplastic human breast epithelial cell lines. Electrophoresis 19: 333-343, 1998. 